\title{
Determinan Perilaku Konsumtif Mahasiswa
}

\author{
Determinants of Student Consumtive Behavior
}

Oleh:

\begin{abstract}
Adibah Yahya
Universitas Pelita Bangsa

adibah.yahya@pelitabangsa.ac.id

Submit: 16 Feb 2021

Review: 18 Apr 2021

Accept: 28 May 2021

Publish: 29 May 2021

ABSTRAK

Perilaku konsumtif mahasiswa dipengaruhi oleh beberapa faktor antara lain literasi keuangan, gaya hidup hedonis, dan uang elektronik. Tingkat literasi keuangan yang tinggi akan menurunkan perilaku konsumtif seseorang jika diterapkan dalam kehidupan sehari-hari. Gaya hidup hedonis yang lebih mementingkan kesenangan pribadi dan penggunaan uang elektronik akibat perkembangan teknologi berpengaruh terhadap tindakan seseorang dalam perilaku konsumen. Penelitian ini bertujuan untuk mengetahui pengaruh literasi keuangan, gaya hidup hedonis, dan uang elektronik terhadap perilaku konsumtif. Populasi yang digunakan adalah seluruh mahasiswa Program Diploma Akuntansi Universitas Pelita Bangsa yang berjumlah 420 responden, dan teknik pengambilan sampel menggunakan purposive sampling maka sampel dalam penelitian ini sebanyak 50 responden. Penelitian analisis regresi berganda digunakan dalam penelitian ini. Hasil penelitian menyatakan bahwa literasi keuangan dan uang elektronik tidak berpengaruh terhadap perilaku konsumtif, namun gaya hidup hedonis mempengaruhi perilaku konsumtif
\end{abstract}

Kata kunci:

Literasi keuangan; gaya hidup hedonis; uang elektronik; perilaku konsumtif.

\begin{abstract}
Student consumptive behavior is influenced by several factors, including financial literacy, hedonic lifestyles and electronic money. A high level of financial literacy will reduce one's consumptive behavior if applied in daily life. The hedonist lifestyle that is more concerned with personal pleasure and the use of electronic money due to technological developments has an influence on one's actions in consumer behavior. The aim of this study is to find out the effect of financial literacy, hedonic lifestyle and electronic money on consumptive behavior. The population used is all students of Diploma in Accounting Pelita Bangsa University, amounting to 420 respondents, and the sampling technique using purposive sampling then the sample in this study about 50 respondents. Multiple regression analysis research is used in this study. The results of the study stated that financial literacy and
\end{abstract}


electronic money have no effect on consumptive behavior. Whereas hedonic lifestyle influences consumptive behavior.

\section{Keywords:}

Financial literacy; hedonic lifestyle; electronic money; consumptive behavior.

\section{PENDAHULUAN}

Peran mahasiswa dalam kehidupan bermasyarakat sebagai penggerak perubahan, memiliki peran pengendalian sosial dan penerus kepemimpinan. Mahasiswa memiliki pendidikan yang lebih tinggi diharapkan lebih kritis terhadap problematika yang terjadi di masyarakat. Mahasiswa digambarkan sebagai seseorang yang memiliki kemampuan yang seimbang dalam memahami transformasi dan perkembangan dunia pendidikan dan lingkungan masyarakat. Mahasiswa diharapkan dapat memanfaatkan pengetahuan dan kemampuan intelektualnya ketika terjun ke masyarakat (Ramadhan, 2015).

Kemampuan yang harus dimiliki oleh mahasiswa salah satunya adalah kemampuan dalam mengelola keuangan. Mahasiswa diharapkan dalam mengelola keuangan secara pribadi. Melalui pengelolaan keuangan pribadi, mahasiswa dapat membuat rencana untuk menentukan kehidupan saat ini maupun masa depan. Pengelolaan keuangan sangat penting untuk meminimalisir perilaku konsumtif (Sari, 2015).

Perilaku konsumsi mahasiswa memiliki banyak perubahan. Perubahan yang terjadi sangat dipengaruhi oleh perkembangan teknologi yang semakin canggih dan informasi yang semakin cepat, membuat kebutuhan mahasiswa menjadi lebih kompleks. Dengan kebutuhan yang semakin kompleks membuat mahasiswa manjadi lebih konsumtif (Kanserina, 2015).
Fenomena perilaku konsumtif banyak terjadi dikalangan mahasiswa, kerenapada masa remaja menginjak dewasa seseorang masih mencari jati diri. Pada masa remaja individu akan cenderung menyukai berbagai halbaru yang cukup menantang bagi dirinya, hal tersebut dikarenakan remaja berupaya untuk mencapai kemandirian dan menemukan identitas dirinya. Sementara remaja akan mengalami perubahan fisik, mental, hobi, dan keinginan (Anggraini, Fauzan, \& Santhoso, 2017). Pemuasan keinginan mahasiswa menjadi tak menentu yang mengakibatkan mahasiswa menjadi lebih konsumtif. Haltersebut dimanfaatkan oleh berbagai macam produk yangmenargetkan pemasarannya kepada remaja, misalnya pakaian,kosmetik, sepatu dan lain-lain.

Perilaku konsumtif harus diiringi dengan pemahaman mengenai pengetahuan mengelola uang dengan baik. literasi keuangan sangat bermanfaat bagi mahasiswa untuk menghindari perilaku konsumtif. Untuk menghindari perilaku konsumtif diperlukan tingkat pengetahuan, keterampilan, keyakinan yang mempengaruhi sikap dan perilaku dalam mengambil keputusan pengelolaan keuangan. Tingkat pengetahuan dan sikap tersebut merupakan literasi keuangan (Udayanthi, Herawati, \& Julianto, 2018). Manfaat literasi keuangan yaitu untuk mendorong pemberian pemahaman mengenai pengelolaan uang agar dapat mengambil kesempatan untuk meraih kehidupann yang lebih baik di masa yang akan datang. Dengan literasi keuangan, 
seseorang dapat mengambil keputusan yang berhubungan dengan kegiatan investasi untuk tujuan yang telah ditetapkan sebelumnya.

Kebutuhan dasar yang dimiliki setiap orang dalam mengelola keuangan serta teknik melakukan investasi untuk mencapai kesejakteraan di masa depan serta terhindar dari problem keuangan dengan memahami literasi keuangan. Literasi keuangan menekankan kepada bagaimana menabung untuk masa depan melalui pengetahuan dan kemampuan dalam mengaplikasikannya (knowledge and ability) (Lusardi, Mitchell, \& Curto, 2010) .

Survei Nasional Literasi dan Inklusi Keuangan (SNLIK) ketiga yang dilakukan Otoritas Jasa Keuangan (OJK) pada tahun 2019 menunjukkan "indeks literasi keuangan sebesar 38,03\% dan indeks inklusi keuangan sebesar 76,19\%. Angka tersebut meningkat dibanding hasil SNLIK pada 2013, yaitu indeks literasi keuangan $21,84 \%$ dan indeks inklusi keuangan $59,74 \%$. Indeks literasi keuangan tahun 2016 sebesar 29,7\% dan indeks inklusi keuangan 67,8\%". Dengan demikian telah terjadi peningkatan pemahaman keuangan (OJK, 2019).

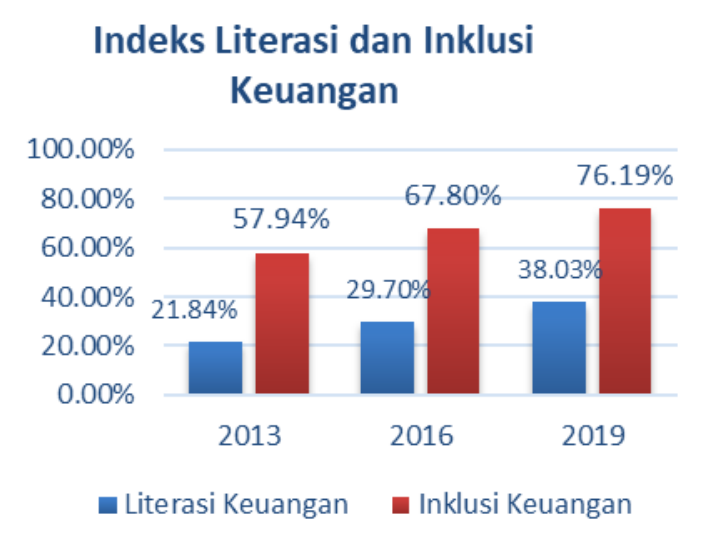

Gambar 1. Indeks Literasi Keuangan dan Inklusi Keuangan

Sumber : (OJK, 2019)

Survei tersebut menunjukkan bahwa masyarakat Indonesia belum memiliki tingkat pengetahuan yang cukup dalam memanfaatkan secara maksimal uang untuk kegiatan yang lebih bernilai. Ketidaktahuan mahasiswa akan literasi keuangan serta sikap konsumtif dan boros mahasiswa juga merupakan masalah yang dihadapi oleh mereka (Rantelobo \& Sir, 2018).

Semakin tinggi tingkat literasi keuangan seseorang menandakan bahwa semakin rendah perilaku konsuntif, yang berarti bahwa seseorang yang memiliki pengetahuan mengenai keuangan cenderung memikirkan masa depannya sehingga mengurangi perilaku konsumtifnya (Julian, Ananda, \& Andriani, 2018; Pulungan \& Febriaty, 2018; Tribuana, 2020; Wahyuni, Irfani, \& Syahrina, 2019).

Gaya hidup menentukan sikap dan perilaku keuangan masyarakat. Mahasiswa lebih mementingkan gaya hidup mereka dibandingkan membeli peralatan untuk perkuliahan. Mahasiswa melihat gaya hidup dari lingkungan kampus, taman sebaya dan teman sepermainan. Perilaku seseorang digambarkan melalui gaya hidup, yaitu bagaimana ia menjalani kehidupannya, bagaimana ia menggunakan uangnya dalam memenuhi kebutuhan dan berbelanja serta memanfaatkan waktu yang dimilikinya. Perubahan gaya hidup mahasiswa, bukan disebabkan oleh perubahan kebutuhan (Melina \& Wulandari, 2013).

Gaya hidup mahasiswa saat ini dalam mengelola keuangan menjadi tidak terkendali. Mahasiswa tidak membuat perencanaan pengeluaran dan pemasukan keuangan. Gaya hidup mahasiswa juga didukung oleh perkembangan teknologi yang sangat pesat. Dengan teknologi mahasiswa tidak lagi harus keluar rumah untuk membeli produk yang diinginkan, cukup membuka smarphone produk yang diinginkan akan muncul. Pembayaran 
produkpun tak perlu untu pergi ke ATM, cukup dengan membayar melalui elektronic money atau sering disebut E-Money (Wahyuni, Irfani, Syahrina, \& Mariana, 2019).

Remaja gemar mencoba sesuatu yang baru karena rasa penasarannyayang tinggi, disamping lebih berorientasi pada lingkungan pergaulan yang membuatnya menjadi berperilaku boros. Mahasiswa merupakan bagian dari salah satu kelompok konsumen remaja. Gaya hidup hedonis sangat berbahaya bagi keuangan mahasiswa karena membuat keuangan mahasiswa tidak memiliki perencanaan. Gaya hidup yang hedonis membuat mahasiswa tidak bisa merencanakan keputusan keuangan dengan baik (Sartika \& Hudaniah, 2018).

Gaya hidup hedonis menandakan gaya hidup yang mengikuti kesenangan hidup tanpa memikirkan akibatnya. Ketika seseorang memiliki gaya hup hedonis, cederung memiliki perilaku konsumtif (Abadi, Utomo, \& Yusdita, 2020; Anggraini et al., 2017; Khairat, Yusri, \& Yuliana, 2019; Puryasari, 2019; Rahmat, Asyari, \& Puteri, 2020). Namun hal tersebut tidak berpengaruh perilaku konsumsi islam (Sukma \& Canggih, 2021).

Cara efektif dalam meningkatkan pemahaman literasi keuangan dapat ditunjang melalui layanan keuangan digital. Namun penggunaan layanan keuangan digital harus diimbangi dengan pemahaman terhadap fungsi, manfaat dan risiko layangan keuangan digital. Salah satu layanan tersebut adalah layanan uang elektronik.

Penggunaan uang elektronik dinilai memberikan kemudahan dan keamanan dalam bertransaksi. Penggunaan uang elektronik di Indonesia saat ini mengalami peningkatan lebih dari $100 \%$ dari tahun 2010 hingga 2016, jumlahnya mencapai 51,2 juta (OJK, 2019). Penggunaan uang elektronik berpengaruh terhadap perilaku konsumtif, namun hal tersebut tidak berlaku pada perilaku konsumsi islam (Sukma \& Canggih, 2021).

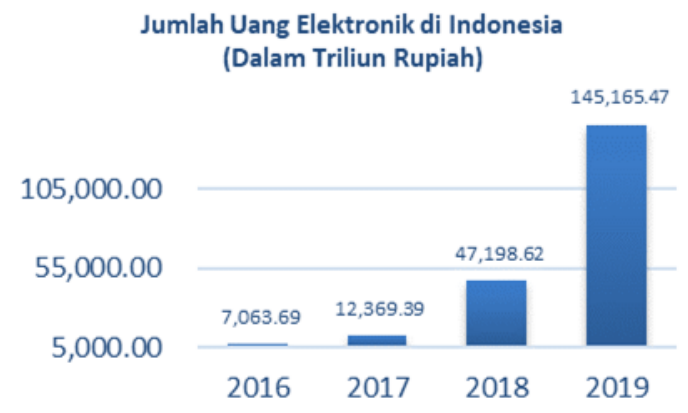

Gambar 2. Jumlah uang elektronik

Sumber: (bi.go.id, 2019), data diolah 2021

Peningkatan penggunaan uang elektronik pada gambar 2 terlihat sejak tahun 2016 sampai 2019 mengalami peningkatan yang yang signifikan yaitu di tahun 2016 sebesar 7.063,69 triliun dan di tahun 2019 sebesar 145.165,47 naik lebih dari $1.000 \%$. Hal ini menunjukkan bahwa penggunaan uang elektronik semakin diminati oleh masyarakat umum. Berikut data penggunaan transaksi uang elektronik tahun 2016 - 2019 (bi.go.id, 2019).

Mahasiswa sebagai generasi penerus bangsa diharapkan memiliki pemikiran yang intelek dan mampu untuk memajukan bangsa dengan pengetahuan yang dimiliki. Mahasiswa Diploma III Akuntansi mendapatkan materi pembelajaran mengenai manajemen keuangan dimana pada mata kuliah tersebut diajarkan mengenai literasi keuangan. Diharapkan mahasiswa memiliki tingkat literasi yang tinggi dalam mengelola keuangan tanpa dipengaruhi oleh gaya hidup hedonis yang mengedepankan kemewahan serta mampu mengendalikan diri dalam pemakaian uang elektronik, sehingga mahasiswa mampu mengendalikan perilaku konsumtifnya. 


\section{METODE PENELITIAN}

\section{Pengembangan Model}

\section{Perilaku Konsumtif}

Pembelian barang yang didasarkan atas keinginan tanpa memeprhatihan keguanan dan manfaat cenderung membuat seseorang menjadi konsumtif (Wahyuni, Irfani, Syahrina, et al., 2019). Akibat perilaku konsumtif yang dilakukan secara terus menerus akan menimbulkan kondisi keuangan yang tidak terkontrol yang memicu terjadinya pembororsan karena pembelian yang dilakukan secara berlebihan dan terus menerus yang menyebabkan terjadinya penumpukan barang (Astuti, 2013)

Pola perilaku konsumtif didasarkan pada kecenderungan atas kesenangan pribadi dan hasrat kebendaan, dimana pembelian produk lebih mementingkan faktor keinginan dibandingkan dengan kebutuhan (Kurniawan, 2017). Perilaku konsumtif merupakan perilaku yang memiliki kecenderungan untuk menggunakan sesuatu tanpa membedakan antara keinginan dan kebutuhan yang diindikasikan melalui dorongan hidup mewah dan berlebihan demi memuaskan hasrat pribadi dan kenyamanan fisik, perilaku ini tidak didasarkan pertimbangan yang rasional (Triyaningsih, 2011).

Faktor-faktor yang mempengaruhi perilaku konsumtif diantaranya (1) Ingin menjadi trend setter, (2) Keinginan memiliki barang branded, (3) mengikuti perkembangan zaman, (4) ingin menarik perhatian orang lain (Kurniawan, 2017). Sedangkan Sumarsono dalam (Astuti, 2013) menyatakan bahwa parameter perilaku konsumtif yaitu: (1) Belanja produk karena hadiah atau diskon; (2) Belanja produk karena kemasan yang menarik perhatian, (3) Belanja produk untuk penampilan diri dan gengsi, (4) Belanja produk karena perbandingan harga (bukan manfaat atau kegunaannya), (5) Belanja produk karena mempertahankan prestise, (6) Penggunaan produk karena ingin dianggap sama dengan model yang mengiklankan, (7) Timbulnya rasa percaya diri tinggi karena memiliki produk dengan harga mahal, (8) Keinginan untuk menguji produk sejenis dengan merek yang berbeda.

\section{Literasi Keuangan dan perilaku konsumtif}

Pengambilan keputusan dan pengelolaan keuangan yang baik dipengaruhi oleh tingkat pengetahuan, keterampilan dan keyakinan terhadap lembaga, produk san layanan keuangan yang dibarengi dengan sikap dan perilaku. Salah satu cara untuk menmbangkitkan sensibilitas masyarakat terhadap sektor keuangan dimulai dengan mempelajaru, memahami kemudian meyakini sampai menjadi terampil untuk berperan serta aktif untuk mencapai masyarakat yang well litterate pada sektor jasa keuangan (Udayanthi, Herawati, \& Julianto, 2013).

Otoritas Jasa Keuangan (OJK) menjelaskan pengertian "literasi keuangan sebagai suatu rangkaian proses atau kegiatan untuk meningkatkan pengetahuan (knowledge), keterampilan (skill), dan keyakinan (confidence) masyarakat agar mereka mampu mengelola keuangan pribadi dengan lebih baik" (OJK, 2017). Setiap individu sepatutnya memiliki literasi keuangan agar terbebas dari permasalahan keuangan karena seringkali menghadapi situasi trade off dimana seseorang harus merelakan salah satu kebutuhan demi kebutuhan lainnya (Ramadhani, 2019).

Literasi keuangan dapat didefinisikan sebagai pengetahuan dan keterampilan pengelolaan keuangan untuk mewujudkan tujuan di masa yang akan datang. Untuk itu mahasiswa harus mengetahui pengelolaan keuangan bagaimana 
pengeluaran uang dan manfaatnya untuk kehidupan keuangannya. Berapapun pendapatannya jika bisa mengatur keuangan dapat menimalisir resiko keuangan (Lusardi et al., 2010).

(Mandell, 2008) Literasi keuangan sebagai kemampuan dalam melakukan evaluasi atas instrumen keuangan yang baru dan kompleks, kemudian membuat penilaian atas instrumen dan tingkat pengunaan dalam rangka mewujudkan tujuan jangka panjang terbaik bagi diri mereka sendiri. Literasi hutang menjadi komponen penting dari literasi keuangan dalam pengambilan keputusan mengenai hutang secara alami dan mengimplementasikan pengetahuan yang dimiliki dalam kehidupan sesungguhnya (Lusardi \& Tufano, 2009).

Organization for Economic Co-operation and Development

(OECD) mengkonseptualisasikan literasi keuangan sebagai "pengetahuan dan pemahaman konsep keuangan dan risiko, dan keterampilan, motivasi dan kepercayaan diri untuk menerapkan pengetahuan dan pemahaman tersebut untuk membuat keputusan yang efektif di berbagai konteks keuangan , untuk meningkatkan kesejahteraan finansial individu dan masyarakat, dan untuk memungkinkan partisipasi dalam kehidupan ekonomi "(OECD, 2014).

Semakin tinggi tingkat literasi keuangan, maka perilaku konsumtif semakin dapat dikendalikan. Hal ini menunjukkan bahwa literasi keuangan memiliki pengaruh negatif terhadap perilaku konsumtif (Julian et al., 2018; Pulungan \& Febriaty, 2018; Tribuana, 2020; Wahyuni, Irfani, \& Syahrina, 2019). Berdasarkan hal tersebut maka pembentukan hipotesis sebagai berikut:

$\mathrm{H}_{1}$ : Literasi keuangan berpengaruh terhadap perilaku konsumtif

\section{Gaya Hidup Hedonis dan perilaku konsumtif}

Gaya hidup negatif yang muncul akibat modernisasi dan perubahan nilai yaitu gaya hidup hedonis. Kehidupan remaja cenderung mengikuti gaya hidup hedonis, gaya hidup ini merupakan pola perilaku yang dapat ditemukan melalui tindakan, ketertarikan dan opini yang mengutamakan pada pemuasan kebutuhan materi untuk mencapai kesenangan hidup (Sukarno \& Indrawati, 2018).

Motivasi hedonis tumbuh karena adanya kebutuhan yang bersifat psikis seperti rasa ingin puas, gengsi, emosi dan perasaan subjektif lainnya (Mulianingsih, 2019). Gaya hidup ini hanya mementingkan kesenangan pribadi dan tidak memperdulikan ketidaksenangan. Hedonisme adalah pemahaman mengenai usaha seseorang untuk hidup dengan mencari kesenangan sebagai tujuan utamanya, terutama untuk dirinya sendiri (Ariyanti, 2019). Mahasiswa yang memiliki gaya hidup hedonis memiliki sifat ingin terlihat berbeda dari yang lainnya. Mahasiswa akan lebih menghabiskan waktunya diluar rumah, hange out bersama teman-teman di mall, membeli barangbarang yang bermerek (branded).

Unsur yang mempengaruhi gaya hidup hedonis yaitu: (1) Unsur internal, yaitu perasaan untuk memuaskan kesenangan pribadi, (2) Unsur eksternal, diantaranya masuknya globalisasi sehingga mengubah pandangan dan mengamati kultur serta kebiasaan dari luar. Dengan perkembangan teknologi seperti internet, kesenangan dapat diperoleh dengan mudah sehingga perilaku masyarakat mengalami perubahan (Ariyanti, 2019).

Seseorang yang memiliki gaya hidup hedonis cenderung melakukan perilaku konsumtif (Abadi et al., 2020; Anggraini et 
al., 2017; Khairat et al., 2019; Puryasari, 2019; Rahmat et al., 2020). Sehingga hipotesis kedua yaitu:

$\mathrm{H}_{2}$ : Gaya Hidup Hedonis berpengaruh terhadap perilaku konsumtif

\section{Uang Elektronik (Electronic Money) dan perilaku konsumtif}

Uang elektronik atau Electronic money (e-money) adalah suatu produk stored-value atau prepaid dimana uang disimpan dalam suatu media elektronik yang dimiliki seseorang. Uang elektronik (e-money) adalah "alat pembayaran elektronik yang diperoleh dengan menyetorkan terlebih dahulu sejumlah uang kepada penerbit, baik secara langsung, maupun melalui agen-agen penerbit, atau dengan pendebitan rekening di bank, dan nilai uang tersebut dimasukan menjadi nilai uang dalam media uang elektronik, yang dinyatakan dalam satuan Rupiah, yang digunakan untuk melakukan transaksi pembayaran dengan cara mengurangi secara langsung nilai uang pada media uang elektronik tersebut" (Ramadhani, 2019).

Menurut Bank Indonesia, uang elektronik dijelaskan sebagai "alat pembayaran dalam bentuk elektronik dimana nilai uangnya disimpan dalam media elektronik tertentu. Penggunanya harus menyetorkan uang terlebih dahulu kepada penerbit dan disimpan dalam media elektronik sebelum menggunakannya untuk keperluan bertransaksi" (bi.go.id, 2013).

Definisi uang elektronik dilihat dari segi sistem informasi (Kim, Lee, \& Shin, 2013): Konsep penggunaan uang elektronik yaitu dengan mengaktifkan fungsi uang melalui peralatan elektronik, kemudian dijelaskan melalui sinyal digital yang dikirim bank untuk menjamin nilai nominal mengenai informasi akan nilai uang. Dapat didefinisikan bahwa uang elektronik adalah uang yang diberikan kepada penerbit dengan nilai moneter tertentu yang disimpan dalam jaringan komunikasi komputer yang dibangun dalam kartu plastik untuk digunakan dalam jaringan komunikasi informasi.

Manfaat dari uang elektronik diantaranya memberikan fasilitas layanan yang cepat dalam melakukan transaksi non tunai, tidak perlu menerima uang receh sebagai uang kembalian, dapat dipakai untuk transaksi yang nilainya kecil dan bersifat massal. Disamping manfaat adapula risiko yang harus dihadapi dalam menggunakan uang elektronik, yaitu (1) risiko uang elektronik hilang, dan dapat dimanfaatkan oleh pihak lain, (2) risiko bagi pengguna yang masih kurang memahami penggunaan uang elektronik (bi.go.id, 2013).

Penggunaan uang elektronik yang semakin meningkat dapat meningkatkan perilaku konsumtif, dikarenakan kemudahan dan kecepatan dalam bertransaksi cenderung membuat seseorang melakukan transaksi yang berlebihan (Insana \& Johan, 2020; Ramadani, 2016; Ramadhani, 2003). Maka hipotesis terbentuk sebagai berikut:

$H_{3}$ : Uang elektronik berpengaruh terhadap perilaku konsumtif

\section{Jenis Penelitian}

Jenis penelitian ini adalah penelitian asosiatif. Penelitian asosiatif adalah penelitian yang bersifat kausal (menjelaskan hubungan antara dua variabel atau lebih) dan hubungan yang bersifat sebab akibat, terdapat variabel bebas dan variabel terikat (Sugiyono, 2017) Penelitian ini menganalisis hubungan tersebut untuk menguji pengaruh literasi keuangan, uang elektronik, dan gaya hidup hedonis terhadap perilaku konsumtif mahasiswa. 


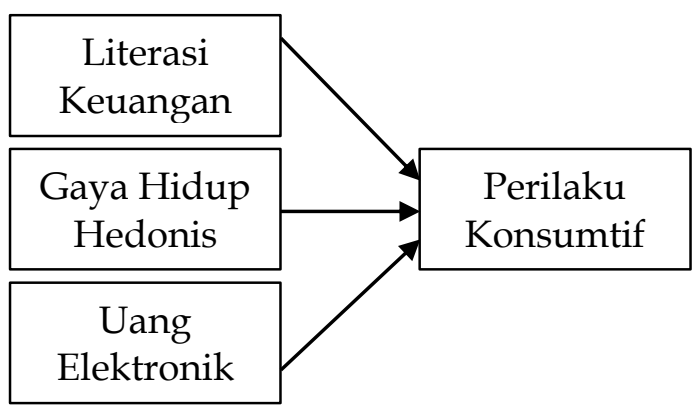

Gambar 3. Model Penelitian

Sumber: data diolah, 2021

\section{Pengumpulan Data}

Populasi penelitian adalah mahasiswa program studi Diploma tiga Akuntansi Universitas Pelita Bangsa. Bagian dari jumlah dan karakteristik yang dimiliki oleh populasi dinamakan sebagai sampel (Sugiyono, 2017). Teknik pengambilan sampel dalam penelitian ini menggunakan purposive sampling, yaitu pemilihan sampel didasarkan pada penetapan kriteria yang sejalan dengan tujuan penelitian, sehingga diharapkan mampu menjawab masalah penelitian. Adapun kriteria pemilihan sampel sebagai berikut: 1) Mahasiswa aktif Diploma tiga jurusan Akuntansi Universitas Pelita Bangsa yang sudah mengambil mata kuliah manajemen keuangan; 2) Mahasiswa yang pernah atau sedang menggunakan electronic money.

Dalam hal ini peneliti menyebarkan kuesioner atas penelitian kepada seluruh mahasiswa program studi Diploma tiga Akuntansi sebanyak 420 responden melalui google form. Adapun yang menanggapi atas kuesioner tersebut dan sesuai kriteria sebanyak 50 responden. Sehingga yang dijadikan sampel penelitian sebanyak 50 responden.

\section{Metode Analisis}

Data dianalisis menggunakan analisis regresi linier ganda yang pengolahannya menggunakan software SPSS. Analisis regresi berganda digunakan untuk mengetahui seberapa besar pengaruh variabel bebas $(X)$ yang terdiri dari literasi keuangan (X1), gaya hidup hedonis (X2), uang elektronik (X3) terhadap variabel terikat (Y) yaitu perilaku konsumtif. Tahapan analisis meliputi uji validitas, reliabilitas, normalitas, model dan hipotesis.

Pengujian validitas atas kuesiner dengan jalan membandingkan $r$ hitung terhadap rtabel. Valid jika nilai $\mathrm{R}$ hitung $>$ R tabel.

Pengujian reliabilitas dalam penelitian ini dilakukan dengan nilai cronbach alpha $>0.060$ yang sudah dikategorikan memiliki tingkat reliabilitas yang mencukupi (Sugiyono, 2017). Jika koefisien cronbach alpha kurang dari 0.060 maka instrumen tersebut dinyatakan tidak reliabel.

Uji Normalitas menggunakan pendekatan grafis (normal p-p plot) dan kolmogorov smirnov dengan nilai probabilitas lebih dari 0,05. Kriteria normal jika nilai residual pada grafis berada disepanjang garis diagonal dan probabilitas kolmogorov lebih dari 0,05.

Uji model menggunakan adj. R Square dan uji-F. Pengujian dengan membandingkan Fhitung terhadap Ftabel dimana model layak jika Fhitung $>$ Ftabel pada tingkat kepercayaan 95\% ( $a=0,05)$ adalah 2,8.

Uji hipotesis menggunakan koefisien regresi dan uji-t. Hipotesis diterima jika koefisien regresi tidak sama dengan nol dan probabilitas $\mathrm{t}$ (Sig. t) lebih kecil atau sama dengan 0,05 .

\section{HASIL PENELITIAN}

\section{Uji Validitas}

Uji instrumen penelitian disajikan pada tabel 1. Terdapat data tidak valid pada variabel perilaku konsumtif. Untuk variabel perilaku konsumtif hanya 
digunakan 8 pertanyaan yang dimasukkan ke dalam pengujian.

Tabel 1. Uji Validitas

\begin{tabular}{cccc}
\hline Literasi & Keuangan & & \\
\hline Item & Rhitung & Rtabel & Kesimpulan \\
\hline P1 & 0,568 & 0,2787 & Valid \\
P2 & 0,593 & 0,2787 & Valid \\
P3 & 0,699 & 0,2787 & Valid \\
P4 & 0,496 & 0,2787 & Valid \\
P5 & 0,606 & 0,2787 & Valid \\
P6 & 0,645 & 0,2787 & Valid \\
P7 & 0,728 & 0,2787 & Valid \\
P8 & 0,393 & 0,2787 & Valid \\
P9 & 0,424 & 0,2787 & Valid \\
P10 & 0,430 & 0,2787 & Valid \\
\hline Gaya Hidup Hedonis & \\
\hline P1 & 0,489 & 0,2787 & Valid \\
P2 & 0,519 & 0,2787 & Valid \\
P3 & 0,715 & 0,2787 & Valid \\
P4 & 0,580 & 0,2787 & Valid \\
P5 & 0,761 & 0,2787 & Valid \\
P6 & 0,721 & 0,2787 & Valid \\
P7 & 0,618 & 0,2787 & Valid \\
\hline Uang Elektronik & & \\
\hline P1 & 0,799 & 0,2787 & Valid \\
P2 & 0,835 & 0,2787 & Valid \\
P3 & 0,872 & 0,2787 & Valid \\
P4 & 0,855 & 0,2787 & Valid \\
P5 & 0,650 & 0,2787 & Valid \\
\hline Perilaku Konsumtif & & \\
\hline P1 & 0,556 & 0,2787 & Valid \\
P2 & 0,640 & 0,2787 & Valid \\
P3 & 0,064 & 0,2787 & Tidak Valid \\
P4 & 0,720 & 0,2787 & Valid \\
P5 & 0,695 & 0,2787 & Valid \\
P6 & 0,716 & 0,2787 & Valid \\
P7 & 0,648 & 0,2787 & Valid \\
P8 & 0,564 & 0,2787 & Valid \\
P9 & 0,633 & 0,2787 & Valid \\
\hline Sumber & SPS, & \\
\hline
\end{tabular}

Sumber: SPSS, data diolah 2021

\section{Uji Reliabilitas}

Rangkuman hasil uji reliabilitas disajikan pada tabel 2. Nilai cronbach's alpha seluruh variabel lebih dari 0,060 sehingga dapat disimpulkan bahwa seluruh variabel dinyatakan reliabel.

Tabel 2. Hasil uji reliabilitas

\begin{tabular}{ccc}
\hline Variabel & Cronbach's Alpha & N of Items \\
\hline LK & 0,739 & 10 \\
GH & 0,752 & 7 \\
EM & 0,864 & 5 \\
PK & 0,838 & 8 \\
\hline
\end{tabular}

Sumber: SPSS, data diolah 2021

\section{Uji Normalitas}

Normalitas secara grafis terpenuhi dengan diperolehnya residual yang berada diseputar garis diagonal pada gambar 4 . Normalitas menggunakan kolmogorov smirnov terpenuhi dengan nilai probabilitas 0,200 yang telah lebih dari 0,05 .

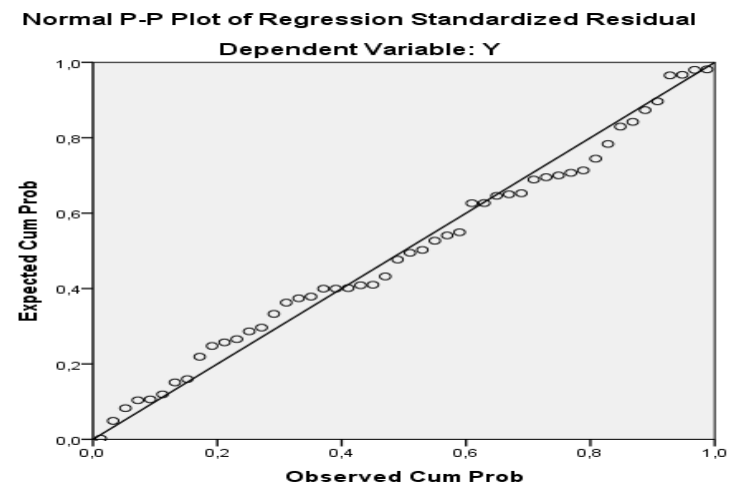

Gambar 4. P-Plot Normalitas

Sumber: SPSS, 2021

Tabel 3. One-Sample KolmogorovSmirnov Test

\begin{tabular}{llr}
\hline \multicolumn{3}{c}{ Unstandardized Residual } \\
Normal & Mean & 50 \\
Parametersa,b & &, 0000000 \\
& Std. Deviation & 4,17472729 \\
Most Extreme & Absolute &, 080 \\
Differences & Positive &, 080 \\
& Negative &,- 061 \\
& &, 080 \\
Test Statistic & $, 200 \mathrm{c}, \mathrm{d}$ \\
$\begin{array}{l}\text { Asymp. Sig. } \\
\text { (2-tailed) }\end{array}$ & & \\
\hline
\end{tabular}

Sumber: SPSS, data diolah 2021 


\section{Uji Model}

Uji model mendapatkan nilai Fhitung adalah 5,79 dengan tingkat signifikansi 0,02 pada tabel 5 . Karena Fhitung $(5,79)>$ Ftabel $(2,8)$ dan tingkat signifikansinya 0,02 $<$ 0,05 menunjukkan bahwa variabel independen (literasi keuangan, gaya hidup hedonis, dan elektronik money) secara serempak berpengaruh signifikan terhadap perilaku konsumtif. Pada tabel 5, terlihat bahwa nilai Adjusted $\mathrm{R}$ Square sebesar 0,11 berarti $11 \%$ variasi perilaku konsumtif dapat dijelaskan oleh literasi keuangan, gaya hidup hedonis, uang elektronik.

Tabel 4. Hasil uji simultan (F)

\begin{tabular}{|c|c|c|c|c|c|c|}
\hline \multicolumn{2}{|c|}{ Model } & Sum of Squares Df & \multicolumn{2}{|c|}{ Mean Square $F$} & \multicolumn{2}{|c|}{ Sig. } \\
\hline$\overline{1}$ & Regression & 322,491 & 3 & 107,497 & 5,790 & $\overline{, 002^{b}}$ \\
\hline & Residual & 853,989 & 46 & 18,565 & & \\
\hline & Total & 1176,480 & 49 & & & \\
\hline
\end{tabular}

Sumber: SPSS, data diolah 2021

Tabel 5. Koefisien Determinasi

\begin{tabular}{ccccc}
\hline Model & $\mathrm{R}$ & R Square & Adjusted R Square & $\begin{array}{c}\text { Std. Error of the } \\
\text { Estimate }\end{array}$ \\
\hline 1 &, $451^{\mathrm{a}}$ & 203 &, 111 & 4,50308 \\
\hline
\end{tabular}

Sumber: SPSS, data diolah 2021

Tabel 6. Hasil uji regresi linier berganda

\begin{tabular}{|c|c|c|c|c|c|}
\hline \multirow{2}{*}{ Model } & \multicolumn{2}{|c|}{$\begin{array}{c}\text { Unstandardized } \\
\text { Coefficients }\end{array}$} & \multirow{2}{*}{$\begin{array}{c}\begin{array}{c}\text { Standardized } \\
\text { Coefficients }\end{array} \\
\text { Beta }\end{array}$} & \multirow[t]{2}{*}{$\mathrm{t}$} & \multirow[t]{2}{*}{ Sig } \\
\hline & $\mathrm{B}$ & Std Error & & & \\
\hline (Constant) & 15,497 & 3,913 & & 3,960 & ,000 \\
\hline Literasi Keuangan & ,082 & 151 & 100 & ,547 &, 587 \\
\hline Gaya Hidup Hedonis & ,511 & 167 & ,437 & 3,053 & ,004 \\
\hline Uang elektronik & ,058 & 164 & ,061 & ,352 & ,727 \\
\hline
\end{tabular}

Sumber: SPSS, data diolah 2021

\section{Uji Hipotesis}

Tabel 2 menghasilkan persamaan regresi dari penelitian ini sebagai berikut: $Y=15,497+0,082 X 1+0,511 X 2+0,58 X 3 \ldots .1)$

Nilai koefisien literasi keuangan sebesar 0,082 dengan nilai sig. 0,727 > 0,05 sehingga pengaruhnya tidak signifikan. Nilai koefisien gaya hidup hedonis sebesar 0,511 dengan nilai Sig. 0,004 atau lebih kecil 0,05 sehingga pengaruhnya signifikan. Nilai koefisien uang elektronik sebesar
0,058 memiliki nilai sig. lebih besar dari taraf uji penelitian $(0,727>0,05)$ sehingga pengaruhnya tidak signifikan.

\section{PEMBAHASAN}

\section{Pengaruh Literasi Keuangan terhadap Perilaku Konsumtif}

Literasi keuangan tidak berpengaruh terhadap perilaku konsumtif. Hasil analisis terhadap mahasiswa Diploma tiga 
Akuntansi Universitas Pelita Bangsa. Mahasiswa memiliki pengetahuan yang baik mengenai pengetahuan umum keuangan, pengelolaan uang, tabungan dan investasi serta risiko yang dihadapi namun pengetahuan tersebut belum sepenuhnya diterapkan dalam keseharian. Mahasiswa hanya memperoleh pendidikan atas literasi keuangan dan dijadikan sebagai tambahan wawasan dan referensi. Namun pengetahuan tersebut tidak dapat dijadikan jaminan atas peningkatan indeks literasi keuangan mahasiswa, sehingga variabel literasi keuangan tidak memiliki pengaruh atas bertambah atau berkurangnya perilaku konsumtif mahasiswa Diploma tiga Akuntansi Univeritas Pelita Bangsa. Walaupun mahasiswa memahami literasi keuangan, namun tidak menjadi jaminan mereka berperilaku konsumtif atau tidak.

Hasil penelitian sejalan dengan penelitian yang digagas oleh (Ramadhani, 2003) Namun tidak sejalan dengan (Pulungan \& Febriaty, 2018) yang menyatakan bahwa literasi keuangan memiliki pengaruh negatif pada perilaku konsumtif. Seseorang yang memiliki literasi keuangan yang baik akan dapat mengelola keuangannya dengan baik sehingga terhindar dari masalah keuangan dan mengurangi kecenderungan berperilaku konsumtif. Secara teori jika tingkat pemahaman literasi keuangan tinggi maka perilaku konsumtif akan rendah/turun.

\section{Pengaruh Gaya Hidup Hedonis terhadap perilaku konsumtif}

Gaya hidup hedonis memiliki pengaruh positif dan signifikan terhadap perilaku konsumtif mahasiswa Diploma tiga Akuntansi Universitas Pelita Bangsa. Semakin tinggi gaya hidup hedonis mahasiswa akan semakin tinggi pula perilaku konsumtifnya. Hasil penelitian sejalan dengan penelitian sebelumnya (Abadi et al., 2020; Anggraini et al., 2017; Khairat et al., 2019; Puryasari, 2019; Rahmat et al., 2020; Tribuana, 2020).

\section{Pengaruh Uang Elektronik terhadap Perilaku Konsumtif}

Hasil analisis data membuktikan bahwa uang elektronik tidak berpengaruh terhadap perilaku konsumtif mahasiswa Diploma tiga Akuntansi Universitas Pelita Bangsa. Hasil tersbut dapat disimpulkan bahwa penggunaan uang elektronik tidak mempengaruhi perilaku konsumtif mahasiswa. Walaupun secara fungsinya pengguna uang elektronik akan dengan cepat mengakses transaksi pembayaran, yang mendorong mahasiswa berperilaku konsumtif. Hasil penelitian sejalan dengan hasil penelitian (Insana \& Johan, 2020; Noto, Anniza, \& Serenata, 2019; Ramadani, 2016; Ramadhani, 2003)

\section{KESIMPULAN}

Literasi keuangan tidak berpengaruh terhadap perilaku konsumtif pada mahasiswa Diploma tiga Akuntansi Universitas Pelita Bangsa. Gaya hidup hedonis berpengaruh positif terhadap perilaku konsumtif pada mahasiswa Diploma tiga Akuntansi Universitas Pelita Bangsa. Uang elektronik tidak berpengaruh terhadap perilaku konsumtif pada mahasiswa Diploma tiga Akuntansi Universitas Pelita Bangsa.

Perlu dilakukan penelitian lajutan untuk mendapatkan model yang memiliki tingkat kelayakan model yang lebih baik. Penelitian lanjutan perlu dilakukan pada unit analisis yang lebih luas dan responden yang lebih banyak. 


\section{DAFTAR PUSTAKA}

Abadi, A. F. P., Utomo, S. W., \& Yusdita, E. E. (2020). Studi Perilaku Konsumtif Pada Mahasiswa Pendidikan Akuntansi. Jurnal Benefita, 5(2), 264. https://doi.org/10.22216/jbe.v5i2.4625

Anggraini, R. T., Fauzan, \&, \& Santhoso, H. (2017). Hubungan antara Gaya Hidup Hedonis dengan Perilaku Konsumtif pada Remaja the relationship between hedonic lifestyle and consumptive behavior in adolescents. Gadjah Mada Journal of Psychology, 3(3), 131-140.

Ariyanti, F. (2019). Mengenal Hedonisme, Gaya Hidup Konsumtif Yang Bisa Bikin Keuangan Merana.

Astuti, E. D. (2013). Perilaku Konsumtif dalam Membeli Barang pada Ibu Rumah Tangga di Kota Samarinda. EJournal Psikologi, 1(2), 148-156.

bi.go.id. (2013). Edukasi: Uang Elektronik.

bi.go.id. (2019). Berapa Transaksi Uang Elektronik di Indonesia? | Databoks. Databoks.Katadata.Co.Id, (September), 2019. Retrieved from https://databoks.katadata.co.id/datapublish/2019/11/07/ berapa-transaksi-uangelektronik-di-indonesia

Insana, D. R. M., \& Johan, R. S. (2020). Analisis Pengaruh Penggunaan Uang Elektronik Terhadap Perilaku Konsumtif Mahasiswa Pendidikan Ekonomi Universitas Indraprasta PGRI. Journal of Applied Business and Economics (JABE), 7(2), 209-224.

Julian, E., Ananda, N. A., \& Andriani, S. (2018). Analisis Tingkat Literasi Keuangan Terhadap Perilaku Konsumtif Pada Remaja Sumbawa. Jurnal Manajemen Dan Bisnis, 1(2). https://doi.org/10.37673/jmb.v1i2.15

Kanserina, D. (2015). Perilaku Konsumtif Mahasiswa Jurusan Pendidikan Ekonomi UNDIKSHA 2015. Jurnal Pendidikan Ekonomi Undiksha, 5(1).

Khairat, M., Yusri, N. A., \& Yuliana, S. (2019). Hubungan Gaya Hidup Hedonis Dengan Perilaku Konsumtif Pada Mahasiswi. Al-Qalb: Jurnal Psikologi Islam, 9(2), 130-139. https:// doi.org/10.15548/alqalb.v9i2.861

Kim, H. J., Lee, S. J., \& Shin, I. C. (2013). Design and implementation of in-house electronic money using java cards. International Journal of Smart Home, 7(5), 103-114. https://doi.org/10.14257/ijsh.2013.7.5.11

Kurniawan, C. (2017). Analisis Faktor-Faktor Yang Mempengaruhi Perilaku Konsumtif Ekonomi Pada Mahasiswa. Jurnal Media Wahana Ekonomika, 13(4), 107-118. https://doi.org/http://dx.doi.org/10.31851/jmwe.v13i4.2709

Lusardi, A., Mitchell, O. S., \& Curto, V. (2010). Financial Literacy Among the Young: Evidence and Implications. National Bureau of Economic Research, 358-380.

Lusardi, A., \& Tufano, P. (2009). Debt literacy, financial experiences, and overindebtedness. NBER Working Paper No. 14808, 3, 1-44.

Mandell, L. (2008). Financial literacy of high school students. In Handbook of Consumer Finance Research (pp. 163-183). https:// doi.org/10.1007/978-0-387-75734-6_10

Melina, A., \& Wulandari, S. (2013). Pengaruh Literasi Ekonomi dan Gaya Hidup terhadap Perilaku Konsumtif Mahasiswi Pendidikan Ekonomi STKIP YPM Bangko. Journal of 
Chemical Information and Modeling, 53(9), 1689-1699. https://doi.org/10.1017/CBO9781107415324.004

Mulianingsih, D. (2019). Pengaruh Motivasi Belanja Hedonis Terhadap Kecenderungan Pembelian Impulsif di Online Shop (Survei Online pada Konsumen Zalora Indonesia di Kota Surabaya). Jurnal Administrasi Bisnis (JAB), 66(1), 56-66.

Noto, A. P., Anniza, A., \& Serenata, S. D. T. (2019). Pengaruh uang elektronik terhadap perilaku konsumtif mahasiswa. Center for Open Science.

OECD. (2014). PISA 2012 Results: Students and Money (Volume VI). In Pisa. https://doi.org/10.1787/9789264208094-en

OJK. (2017). Literasi Keuangan.

OJK. (2019). Siaran Pers Survei OJK 2019: Indeks Literasi dan Inklusi Keuangan Meningkat.

Pulungan, D. R., \& Febriaty, H. (2018). Pengaruh Gaya Hidup dan Literasi Keuangan Terhadap Perilaku Konsumtif Mahasiswa. Jurnal Riset Sains Manajemen, 2(3), 1-8. https://doi.org/10.5281/zenodo.1410873

Puryasari, R. (2019). Pengaruh Literasi Ekonomi Dan Gaya Hidup Terhadap Perilaku Konsumtif Mahasiswa Pendidikan Ekonomi Stkip Pgri Tulungagung. UTILITY: Jurnal Ilmiah Pendidikan Dan Ekonomi, 3(1), 1-14. https://doi.org/10.30599/utility.v3i1.520

Rahmat, A., Asyari, A., \& Puteri, H. E. (2020). Pengaruh Hedonisme dan Religiusitas Terhadap Perilaku Konsumtif Mahasiswa. EKONOMIKA SYARIAH : Journal of Economic Studies, 4(1), 39. https://doi.org/10.30983/es.v4i1.3198

Ramadani, L. (2016). Pengaruh Penggunaan Kartu Debit dan Uang Elektronik (E-Money) Terhadap Pengeluaran Konsumsi Mahasiswa. Jurnal Ekonomi Dan Ekonomi Studi Pembangunan, 8(1), 1-8. https://doi.org/10.17977/um002v8i12016p001

Ramadhan, R. (2015). Peran dan Fungsi Mahasiswa. Retrieved from kompasiana.com website: https://www.kompasiana.com/rezaramadhanunj/55dadb8a54977303099134c5/peran -dan-fungsi-mahasiswa

Ramadhani, R. H. (2003). Pengarh Literasi Keuangan, Electronic Money, Gaya Hidup, Dan Kontrol Diri Terhadap Perilaku Konsumtif Mahasiswa (Studi Kasus Mahasiswa Strata1 Manajemen Universitas Sumatera Utara). Skripsi, 4-16.

Ramadhani, R. H. (2019). Pengaruh Literasi Keuangan, Electronic Money, Gaya Hidup, dan Kontrol Diri Terhadap Perilaku Konsumtif Mahasiswa. 114.

Rantelobo, A. T., \& Sir, J. S. (2018). Analisis Jalur Faktor-Faktor yang Mempengaruhi Literasi Finansial dan Perilaku Keuangan Mahasiswa Jurusan Akuntansi Politeknik Negeri Kupang. Jurnal Akuntansi, Keuangan Dan Audit, 3(2), 30-45.

Sari, F. W. (2015). Pengaruh Intelligence Qountient dan Pendidikan Keuangan di Keluarga Terhadap hasil Belajar Mengajar Manajemen Keuangan.

Sartika, Y. D., \& Hudaniah, H. (2018). Gaya Hidup Hedonis Dan Intensi Korupsi Pada Mahasiswa Pengurus Lembaga Intra Kampus. Jurnal Ilmiah Psikologi Terapan, 6(2), 213. https://doi.org/10.22219/jipt.v6i2.7142

Sugiyono, P. D. (2017). Metodologi Penelitian Kuantitatif Kualitatif dan RED. Bandung: Alfabeta. Sukarno, N. F., \& Indrawati, E. S. (2018). Hubungan Konformitas Teman Sebaya Dengan Gaya Hidup Hedonis Pada Siswa Di Sma Pl Don Bosko Semarang. Empati, 7(2), 314-320. 
Sukma, M. N., \& Canggih, C. (2021). Pengaruh Electronic Money, Gaya Hidup dan Pengendalian Diri Terhadap Perilaku Konsumsi Islam. 7(01), 209-215.

Tribuana, L. (2020). Pengaruh Literasi Keuangan, Pengendalian Diri Dan Konformitas Hedonis Terhadap Perilaku Konsumtif Mahasiswa. Prisma (Platform Riset Mahasiswa Akuntansi), 1(1), 145-155. Retrieved from https://ojs.stiesa.ac.id/index.php/prisma

Triyaningsih, S. (2011). Dampak Online Marketing Melalui Facebook Terhadap Perilaku Konsumtif Masyarakat. Jurnal Ekonomi Dan Kewirausahaan, 11(2), 172-177.

Udayanthi, N. O., Herawati, N. T., \& Julianto, I. P. (2013). Pengaruh Literasi Keuangan, Kualitas Pembelajaran dan Pengendalian Diri Terhadap Perilaku Konsumtif (Studi Empiris pada Mahasiswa Jurusan Akuntansi Program S1 Universitas Pendidikan Ganesha). JIMAT (Jurnal Ilmiah Mahasiswa Akuntansi), 9(9), 195-208. https://doi.org/10.1017/CBO9781107415324.004

Udayanthi, N. O., Herawati, N. T., \& Julianto, I. P. (2018). Pengaruh Literasi Keuangan, Kualitas Pembelajaran dan Pengendalian Diri Terhadap Perilaku Konsumtif (Studi Empiris pada Mahasiswa Jurusan Akuntansi Program S1 Universitas Pendidikan Ganesha). JIMAT (Jurnal Ilmiah Mahasiswa Akuntansi), 9(2), 195-208.

Wahyuni, R., Irfani, H., \& Syahrina, I. A. (2019). Pengaruh Gaya Hidup dan Literasi Keuangan Terhadap Perilaku Konsumtif Berbelanja Online Pada Ibu Rumah Tangga di Kecamatan Lubuk Begalung Kota Padang. Jurnal Benefita, 4(3), 548-559.

Wahyuni, R., Irfani, H., Syahrina, I. A., \& Mariana, R. (2019). Pengaruh Gaya Hidup Dan Literasi Keuangan Terhadap Perilaku Konsumtif Berbelanja Online Pada Ibu Rumah Tangga Di Kecamatan Lubuk Begalung Kota Padang. Jurnal Benefita, 4(3), 548. https://doi.org/10.22216/jbe.v4i3.4194 